1 Council on Foreign Relations, Washington, DC, USA

2 Global Health Centre, Graduate Institute of International and Development Studies

Correspondence to: T J Bollyky TBollyky@cfr.org

Cite this as: BMJ 2020;371:m4088 http://dx.doi.org/10.1136/bmj.m4088

Published: 23 October 2020
DEMOCRACY AND HEALTH

\section{Preparing democracies for pandemics}

\section{Tackling inequalities is essential for justice, security, and preparedness}

Thomas J Bollyky, ${ }^{1,1}$ llona Kickbusch²

The coronavirus pandemic is not an advertisement for the health effects of democracy. Several democracies-such as New Zealand, South Korea, Germany, and Uruguay-acted quickly to contain SARS-CoV-2, yet many others-including Brazil, India, the UK, and the US-struggled to respond. As of October 2020, nine of the 10 nations with the highest cumulative cases of covid-19 were democracies. ${ }^{1}$

\section{Health challenges}

The mixed performance of democracies represents a departure from their success in confronting other health challenges, relative to other forms of governments. Over the past 25 years, many studies identified links between democracy and lower death rates in infants and children younger than 5 years, and with longer life expectancy at birth. ${ }^{2}$ Recent research found that democracy is associated with longer adult life expectancy at age 15 and lower mortality from causes such as cardiovascular disease and transport injuries, which are less well targeted by foreign aid and depend on a robust healthcare infrastructure. ${ }^{3}$

Indeed, BMJ's new collection on democracy and health includes a study that concludes that countries in which democracy is being eroded have made less progress on universal health coverage and had higher out-of-pocket spending per head than would have occurred without this autocratisation. ${ }^{4}$

The standard explanation for the health effects of democracies is that regular, free, and fair elections offer governments a greater incentive than autocracies to provide health promoting resources and services to the wider population. ${ }^{5}$ Yet, a survey of voters in India, the UK, and the US finds that respondents did not blame their governments for the spread of covid-19, even though most considered the government somewhat responsible for health generally. ${ }^{6}$

Another explanation for the link between democracy and health is greater freedom of expression.

Democracies are more open to feedback from a broad range of interest groups, more protective of media freedom, and probably more willing to use that feedback to extend and improve effective essential health services. Yet, Wilson and Wisongye found that social media disinformation campaigns exploit the openness of democracies, erode their health benefits, and contribute to increasing vaccine hesitancy and declining vaccination rates. ${ }^{7}$ Similar disinformation campaigns have targeted lockdowns, mask wearing, and other non-pharmaceutical interventions in this pandemic. $^{8}$
In a period of scientific uncertainty about a novel virus, strategies had to be implemented with speed and adapted, sometimes several times. Few countries had planned or prepared the public for the possibility of an extended restriction of personal freedoms in a pandemic. Governments and leaders that have been unable to encourage public trust and social solidarity have struggled. As Prah Ruger notes, a responsive government elected by a free and fair process is not enough in a pandemic: "Just structures that foster security and express care and compassion are essential." 9

\section{Social solidarity}

But the issues go beyond individual freedom to social solidarity. As the pandemic highlights societal inequalities, questions of legitimacy and lack of trust arise in relation to a political system that allows such disparities to fester over decades. Wealthy countries like Switzerland, Germany, and the Nordic welfare states have provided for their citizens, keeping unemployment and poverty at bay, unlike countries in which social protections have never recovered from austerity measures after the 2008 financial crisis. ${ }^{10}$

Democracy remains the preferred form of government worldwide, but measures are needed to better "pandemic proof" this political system. ${ }^{11}$ In some countries, concern is increasing about parliaments being sidelined in decision making. ${ }^{12}$ Easier and safer channels for voting, whether by mail or online, are a prerequisite for accountability of democratic leaders in a pandemic. ${ }^{13} 14$

Most seriously, the pandemic is an entry point for autocratic governments to change laws and introduce restrictions. Populism and nationalism feed off the threat of the virus and question the reliability of science and information.

Little empirical support exists for a single characteristic of government or society-whether women leaders, populism, more equal economies, or universal health coverage-ensuring better performance in a future pandemic. ${ }^{15}{ }^{16}$ German Chancellor Angela Merkel, in her television address on 19 March 2020, emphasised that she spoke as the head of a democracy in which citizens "do not live by coercion, but by shared knowledge and participation." 17

This vision of democracy works in a crisis only if it is promoted in normal times. Freedom, democratic constitutionalism, and a democratic way of life do not come without effort. The pandemic reminds us that personal responsibility and private initiative thrive only if we mutually recognise each other as 
free and equal and protect each other against existential risks. ${ }^{18}$

\section{Sustained investment}

Government trust and social protections require sustained investment in civil society, scientific literacy, public education on the role of science in policy making, and adequate representation of public health specialists and regulators in decision making. Corporate standards on disinformation must be established to promote adequate self-regulation by social media companies. If these investments are first made during a pandemic, it will be too late.

As Dhatt and colleagues argue, the need for representative participation in health decision making extends to global health generally. ${ }^{19}$ Bolstering access to primary health coverage and social safety protections will achieve better, more equitable outcomes in future pandemics. ${ }^{2021}$ The health of vulnerable and marginalised groups must be regularly monitored and reported transparently.

The most important lessons from this pandemic are less about the coronavirus itself but what it has revealed about the political systems that have responded to it. Democratic government must begin the hard task of responding to those lessons before the next pandemic threat arises, which it inevitably will.

Competing interests: We have read and understood BMJ policy on declaration of interests and have no interests to declare.

Provenance and peer review: Commissioned; not externally peer reviewed.

This article is part of a collection launched at the World Health Summit, 25-27 October 2020, Berlin, Germany. Funding for the articles, including open access fees, was provided by a grant from Bloomberg Philanthropies to the Council on Foreign Relations, support from the Konrad-Adenauer-Stiftung to the Graduate Institute of International and Development Studies, and the Institute for Health Metrics and Evaluation.

1 Johns Hopkins University. Covid-19 dashboard by the Center for Systems Science and Engineering (CSSE) at Johns Hopkins University, 21 Jan 2020. https://gisanddata.maps.arcgis.com/apps/opsdashboard/index.html\#/bda7594740fd40299423467b48e9ecf6

2 McGuire JW. Democracy and population health. Elements in the politics of development. Cambridge University Press, 2020.

3 Bollyky TJ, Templin T, Cohen M, Schoder D, Dieleman JL, Wigley S. The relationships between democratic experience, adult health, and cause-specific mortality in 170 countries between 1980 and 2016: an observational analysis. Lancet 2019;393:1628-40. doi: 10.1016/S0140-6736(19)30235-1 pmid: 30878225

4 Wigley S, Dieleman JL, Templin T, Mumford JE, Bollyky TJ. Autocratisation and universal health coverage synthetic control study. BMJ 2020;371:m4040. doi: 10.1136/bmj.m4040.

5 Sen A. Development as freedom. Anchor Books, 1999.

6 Acharya A, Gerring J, Reeves A. Is health politically irrelevant? Experimental evidence during a global pandemic. BMJ Glob Health 2020. doi: 10.1136/bmigh-2020-004206

7 Wilson SL, Wisongye CS. Social media and vaccine hesitancy. BMJ Glob Health 2020. doi: 10.1136/bmigh-2020-004222.

8 Chinese agents helped spread messages that sowed virus panic in US, officials say. New York Times 2020 Apr 22. https://www.nytimes.com/2020/04/22/us/politics/coronavirus-china-disinformation.html

9 Ruger JP. Social justice as a foundation for democracy and health. BMJ2020;371:m4049. doi: 10.1136/bmj.m4049

10 United National Regional Coordination Mechanism Europe and Central AsiaUnited Nations Sustainable Development Group Europe and Central Asia. COVID-19 and social protection in Europe and Central Asia. International Labour Organization, 2020

11 Wike R, Simmons K, Stokes B, et al. Globally, broad support for representative and direct democracy. Pew Research Center, 2017. https://www. pewresearch.org/global/2017/10/16/globally-broad-support-for-representative-and-direct-democracy/

12 Parliament has been sidelined during the Covid crisis. Telegraph 2020 Jun 17. https://www.telegraph.co.uk/opinion/2020/06/17/parliament-has-sidelined-covid-crisis/

13 Belin C. De Maio G. Democracy after coronavirus: five challenges for the. Brookings Institution, 2020s, https://www.brookings.edu/wp-content/uploads/2020/08/FP_20200817_democracy_covid_belin_demaio.pdf.

14 Cuevas Barron G, Bastida X, Calhoun C, et al. COVID-19 and democracy: can parliaments come to the rescue? 2020. https://www.ipu.org/event/covid-19-and-democracy-can-parliaments-comerescue
15 Bosancianu CM, Dionne KY, Hilbig H, et al. Political and social correlates of covid-19 mortality. 2020 Jun 11. https://wzb-ipi.github.io/corona/WD_paper.pdf

16 Crosby S, Dieleman JL, Kiernan S, Bollyky TJ. All bets are off for measuring pandemic preparedness. Think Global Health, 30 Jun 2020. https://www.thinkglobalhealth.org/article/all-bets-are-measuring pandemic-preparedness

17 Novak B, Eddy M, Bennhold K, et al. Locked-down Europe faces closed borders, economic wounds and dire warnings. New York Times2020 Mar 18. https://www.nytimes.com/2020/03/18/world/europe/hungary-borders-europe-coronavirus.html

18 Van Rahden T. Making democracy safe for an age of pandemics. Graduate Institute of Geneva, 2020. https://www.graduateinstitute.ch/communications/news/making-democracy-safe-agepandemics

19 Dhatt R, Maleche A, Were N, Pace L. Investing in civil society for better democracy, better health. BMJ Opinion, 25 Oct 2020.

20 Department of Economic and Social Affairs. Economic Analysis. UN/DESA policy brief 65: responses to the covid-19 catastrophe could turn the tide on inequality. 2020. https://www.un.org/development/desa/dpad/publication/un-desa-policy-brief-65-responses-to-the-covid-19-catastrophecould-turn-the-tide-on-inequality/

21 Burwell SM, Townsend FF, Bollyky TJ, et al. Improving pandemic preparedness: lessons from covid-19. Council on foreign relations independent task force report No 78. 2020.

This is an Open Access article distributed in accordance with the Creative Commons Attribution Non Commercial (CC BY-NC 4.0) license, which permits others to distribute, remix, adapt, build upon this work non-commercially, and license their derivative works on different terms, provided the original work is properly cited and the use is non-commercial. See: http://creativecommons.org/licenses/bync/4.0/. 